\title{
Social Values Perceptions of Fourth Grade Primary School Students
}

\author{
Hakan Cetin (RA) \\ Siirt University Faculty of Education Siirt, Turkey \\ Ozlem Kaf (Asst.Prof.) \\ Çukurova University Faculty of Education Adana, Turkey \\ doi: 10.19044/esj.2017.v13n19p88 URL:http://dx.doi.org/10.19044/esj.2017.v13n19p88
}

\begin{abstract}
This study was conducted with the aim of determining the perceptions of social values of fourth grade primary school students. The research is a descriptive study based on survey model. The study sample group is composed of 451 fourth grade students studying in four different schools in Siirt city center selected via convenience sampling method. The Perception Scale for Social Values developed by Bakaç (2013) was used as data collection instrument. There are a total of 23 five-point likert-type items on The Perception Scale for Social Values, of which 19 items are designed to measure positive perceptions and 4 items are designed to measure negative perceptions. Cronbach-Alpha reliability coefficients of the scale are .88 for the first sub-scale, .72 for the second sub- scale and .86 for the total scale. Descriptive statistics, Mann-Whitney U-Test and Kruskal Wallis methods were used for data analysis. The findings of the study indicate that the social value perceptions of fourth grade students show no significant difference with regard to gender or education level of mother. Whereas it was concluded that the social value perceptions of fourth grade students show a significant difference with regard to place of residence and education level of father
\end{abstract}

Keywords: Social values, primary school, fourth grade

\section{Introduction}

Coping with change is a result of social and psychological development of the individual. People are less successful at adapting to social and psychological changes compared to adapting to material changes. This process is more difficult in people who have not completed their moral development. Societies aiming to eliminate such problems should show utmost efforts to introduce values to bring people together (Gündüz, 2015). 
Recently cultural degeneration has been observed in some societies in line with the globalization concept. Globalization erased national borders and as a result more dominant cultures started to impose themselves on those which are at lower development stages. This phenomenon causes many cultures to crush and vanish under such pressure. These changes, destroying some social sensitivities, cause behaviors such as disobeying social rules, disrespecting parents and drug abuse to emerge among new generations in societies where values such as love, respect and tolerance are still existent (Çubukçu, 2012). The reason for the exaggerated emphasis bestowed upon the values as a popular contemporary concept is not because it is much valued but on the contrary there is a great necessity for it. As a social being essential role of the individual is to adapt to the society in which it exists. One should have certain knowledge at this adaptation stage and be able to exercise these in his/her own life. These knowledge are composed of fully comprehending the values, beliefs and customs and traditions of one's own society (Tural, 1992).Most important work falls into families and schools in order to realize this. Values education ensures not only the individual learning about his/her own culture and values, but also learning about other cultures and universal values and enables him/her to establish a connection between them(Ravinger, 2006). There is no special time and place for values education. However, since the essential parts of the personality are shaped in younger ages, the early years of school education are very important in values education (Doğanay, 2006). Therefore specialists in this field and educators should greatly value and concentrate their efforts on these early years. Gathering information on the value orientations and social values perceptions of individuals at young ages, can help timely correction of bad behavior and also help raising individuals who can make correct decisions and think soundly on social and universal values. In consideration of these explanations, the aim of this study is to examine the social value perceptions of fourth year primary school students with regard to several variables. In line with this overall aim, the following questions were sought answers for;

1) What are the social values perceptions of fourth grade primary school students?

2) Do the social values perceptions of fourth grade primary school students statistically significantly differences with regard to gender, parent education level and place of residence variables?

\section{Method}

This is a descriptive study based on survey model, aiming to examine the social values perceptions of fourth grade primary school students with regard to several variables. 


\section{Population and Sample}

The population of the study comprises students studying in the fourth grade in city center primary schools governed by Siirt Provincial Directorate of National Education in 2015-2016.The sample group of the study consists of a total of 451 fourth grade students enrolled in four different schools selected by convenience sampling, 224 of which 451 (49.7\%) are male and 227 (50.3\%) are female. The number of students whose fathers are illiterate is $34(7.5 \%)$, the number of students whose fathers' education is at primary school level is 128 (28.4\%), the number of students whose fathers' education is at high school level is 123 (27.3\%) and the number of students whose fathers' education is at university level is 166 (36.8\%). The number of students whose mothers are illiterate is 100 (22.2\%), the number of students whose mothers' education is at primary school level is 195 (43.2\%), the number of students whose mothers' education is at high school level is 93 (20.6\%) and the number of students whose mothers' education is at university level is 63 (14\%).

\section{Data Collection Instrument}

The Perception Scale for Social Values developed by Bakaç (2013) was used as data collection instrument. There are a total of 23 five-point likert-type items on The Perception Scale for Social Values, of which 19 items are designed to measure positive perceptions and 4 items are designed to measure negative perceptions. The factor loadings range between .39 and .73 for the first factor and explain $25.69 \%$ of the total variance. The factor loadings range between .54 and .69 for the second factor and explain 10.33\% of the total variance. Cronbach-Alpha reliability coefficients of the scale are .88 for the first sub-scale, .72 for the second sub- scale and .86 for the total scale.

\section{Data Collection and Analysis}

The researchers, after acquiring required permissions, visited the schools and entered classes at convenient times and collected the data. Data collection was completed about in one week. The scale was administered to 726 fourth grade students enrolled in schools located in areas with different socio-economic levels. Following the administration 451 data deemed suitable for analysis out of the total 726, were analyzed. Descriptive statistics, Mann-Whitney U-Test and Kruskal Wallis methods were used for data analysis.

\section{Findings}

Upon examining the social values perceptions of the fourth grade students, it was determined that the following items scored high mean in the 
positive perceptions on social values sub-scale; "Our family protects us from bad people and bad situations" $(\bar{X}=4,51)$, "We should protect both our physical and mental health" ( $\bar{X}=4.45)$, "Respect is learned in the family" ( $\bar{X}$ =4.46), "We should keep our honesty even though we might suffer at the end” ( $\bar{X}=4.46)$, “One should first be honest oneself, so the others will also be honest” ( $\bar{X}=4.47$ ), In the negative perceptions on social values sub-scale the following items have the lowest mean; "We may stray from honesty in order to get what we want" ( $\bar{X}=2.94)$ and "Only scientists should deal with science” ( $\bar{X}=3.09)$

The results of the analysis to determine if social value perceptions vary with gender of the students are presented in Table 1.

Table 1. Mann Whitney U-Test Results of Social Values Perception Levels of Fourth Grade Students with Respect to Gender Variable

\begin{tabular}{cccccccc}
\hline & Gender & N & Median & $\begin{array}{c}\text { Mean } \\
\text { Rank. }\end{array}$ & $\begin{array}{c}\text { Rank } \\
\text { Sum }\end{array}$ & U & p \\
\hline $\begin{array}{c}\text { Positive } \\
\text { Perceptions }\end{array}$ & Male & 224 & 4.57 & 229.88 & 51493.00 & & \\
\hline Female & 227 & 4.52 & 222.17 & 50433.00 & 24555.00 & .53 \\
$\begin{array}{c}\text { Negative } \\
\text { Perceptions }\end{array}$ & Male & 224 & 3.25 & 219.23 & 49108.5 & & \\
\hline
\end{tabular}

Upon examining Table 1 no statistically significant difference was detected in the positive perceptions ( $U=24555, p=.528 ; \mathrm{p}>0.05)$ and negative perceptions

$(\mathrm{U}=23908.5, \mathrm{p}=.271 ; \mathrm{p}>0.05)$ on social values sub-scales with respect to gender variable.

The results of the Kruskal Wallis test to determine if social value perceptions of fourth grade students statistically significant differences with education level of the mother variable are presented in Table 2.

Table 2. The analysis results of the Kruskal Wallis test regarding social value perceptions of fourth grade students with respect to education level of the mother

\begin{tabular}{|c|c|c|c|c|c|c|c|}
\hline & $\begin{array}{l}\text { Education } \\
\text { Level of } \\
\text { Mother }\end{array}$ & $\mathrm{N}$ & Median & $\begin{array}{l}\text { Mean } \\
\text { Rank }\end{array}$ & sd & $X^{2}$ & $\mathrm{p}$ \\
\hline \multirow{4}{*}{$\begin{array}{c}\text { Positive } \\
\text { Perceptions }\end{array}$} & Illiterate & 100 & 4.39 & 198.31 & \multirow{4}{*}{3} & \multirow{4}{*}{6.523} & \multirow{4}{*}{.09} \\
\hline & $\begin{array}{c}\text { Primary } \\
\text { school }\end{array}$ & 195 & 4.57 & 229.21 & & & \\
\hline & High school & 93 & 4.68 & 237.07 & & & \\
\hline & University & 63 & 4.68 & 243.70 & & & \\
\hline \multirow{4}{*}{$\begin{array}{l}\text { Negative } \\
\text { Perceptions }\end{array}$} & Illiterate & 100 & 3.00 & 205.91 & \multirow{4}{*}{3} & \multirow{4}{*}{3.869} & \multirow{4}{*}{.28} \\
\hline & $\begin{array}{l}\text { Primary } \\
\text { school }\end{array}$ & 195 & 3.50 & 229.52 & & & \\
\hline & High school & 93 & 3.25 & 227.52 & & & \\
\hline & University & 63 & 3.75 & 244.75 & & & \\
\hline
\end{tabular}


Upon examining Table 2 no statistically significant difference was detected in the positive perceptions $(\mathrm{H}=6.523$, $\mathrm{sd}=3 \mathrm{p}=.089)$ and negative perceptions $(\mathrm{H}=3.869$, $\mathrm{sd}=3 \mathrm{p}=.276)$ on social values sub-scales with respect to education level of the mother variable.

The results of the Kruskal Wallis test to determine if social value perceptions significantly difference with education level of the father variable are presented in Table 3.

Table 3. The analysis results of the Kruskal Wallis test regarding social value perceptions of fourth grade students with respect to education level of the father

\begin{tabular}{|c|c|c|c|c|c|c|c|}
\hline & $\begin{array}{l}\text { Education } \\
\text { Level of } \\
\text { Father }\end{array}$ & $\mathrm{N}$ & Median & $\begin{array}{l}\text { Mean } \\
\text { Rank }\end{array}$ & Sd & $X^{2}$ & $\mathrm{p}$ \\
\hline \multirow{4}{*}{$\begin{array}{c}\text { Positive } \\
\text { Perceptions }\end{array}$} & Illiterate & 34 & 4.39 & 176.60 & \multirow{4}{*}{3} & \multirow{4}{*}{8.403} & \multirow{4}{*}{$.038^{*}$} \\
\hline & $\begin{array}{c}\text { Primary } \\
\text { school }\end{array}$ & 128 & 4.57 & 234.30 & & & \\
\hline & High school & 123 & 4.47 & 213.10 & & & \\
\hline & University & 166 & 4.68 & 239.28 & & & \\
\hline \multirow{4}{*}{$\begin{array}{l}\text { Negative } \\
\text { Perceptions }\end{array}$} & Illiterate & 34 & 3.00 & 203.65 & \multirow{4}{*}{3} & \multirow{4}{*}{3.236} & \multirow{4}{*}{.36} \\
\hline & $\begin{array}{c}\text { Primary } \\
\text { school }\end{array}$ & 128 & 3.00 & 215.22 & & & \\
\hline & High school & 123 & 3.50 & 227.76 & & & \\
\hline & University & 166 & 3.75 & 237.58 & & & \\
\hline
\end{tabular}

Examining the analysis results from Table 3 regarding social value perceptions of fourth grade students with respect to education level of the father, reveals statistically significant differences $(H=8.403, \mathrm{sd}=3, \mathrm{p}=$ .038)in positive perceptions on social values sub-scales. The Mann Whitney U-Test performed to understand between which education levels exist significant differences are presented in Table 4.

Table 4. The analysis results of the Mann Whitney U Test regarding social value perceptions of fourth grade students with respect to education level of the father

\begin{tabular}{cccc}
\hline \multicolumn{2}{c}{ Education level of father } & $\mathrm{U}$ & $\mathrm{p}$ \\
\hline \multirow{2}{*}{ Positive perceptions } & Primary school $>$ Illiterate & 1636.5 & $.026^{*}$ \\
& University>Illiterate & 2047.5 & $.011^{*}$ \\
\hline
\end{tabular}

Upon examining Table 4 statistically significant difference was detected in favor of students whose fathers are at primary school level ( $\mathrm{U}=$ 1636.5, $\mathrm{p}<.05$ ) between the students whose fathers are at primary school level and the students whose fathers are illiterate and in favor of students whose fathers are at University level $(\mathrm{U}=2047.5, \mathrm{p}<.05)$ between the students whose fathers are at University level and the students whose fathers are illiterate in the positive perceptions on social values sub-scale.

The results of the Kruskal Wallis test to determine if social value perceptions significantly difference with place of residence variable are presented in Table 5. 
Table 5. The analysis results of the Kruskal Wallis test regarding social value perceptions of fourth grade students with respect to the place of residence

\begin{tabular}{cccccccc}
\hline & $\begin{array}{c}\text { Place of } \\
\text { Residence }\end{array}$ & $\mathrm{N}$ & Median & $\begin{array}{c}\text { Mean } \\
\text { Rank }\end{array}$ & sd & $\boldsymbol{X}^{\mathbf{2}}$ & $\mathrm{p}$ \\
\hline Positive & Other & 59 & 4.57 & 217.18 & 1 & .314 & .58 \\
Perceptions & City Center & 392 & 4.57 & 227.33 & & & \\
\hline $\begin{array}{c}\text { Negative } \\
\text { Perceptions }\end{array}$ & Other & 59 & 3.50 & 175.14 & \multirow{2}{*}{1} & & \\
\hline
\end{tabular}

The findings from Table 5 indicate that there are no statistically significant $\mathrm{d}$,fference $(\mathrm{H}=.314$, $\mathrm{sd}=1, \mathrm{p}=.58)$ between groups in positive perceptions on social values sub-scale, there is statistically significant difference in favor of students living in city center $(H=10.426, s d=1, p=$ $.001)$.

\section{Discussion and Conclusion}

Based on these findings it appears that the students favor the values of honesty, respect, health and valuing the family slightly more than other values. Many variables such as social roles adopted, the values emphasized in social life, the roles the society imposes influence the moral development of the individual (Kohlberg, 1969, As cited in Öksüz, 2011). In a recent study employing the data set composed of 600 variables related to Turkey on European Social Survey database, the most important social values were found to be, "self-transcendence" and "conservatism"; and the core values with least importance attributed were "openness to change" and "selfempowerment". Furthermore values such as altruism, sensitivity to people, nature and environment and honesty were noted to be highly emphasized in values studies Turkey has participated in (Özensel, 2007)

"Scientificity" is one of the lowest scoring values in the study. According to Norris and Phillips (2003) the reason why the students have a low tendency towards scientificity is because the students experience difficulty in distinguishing what is scientific and what is not. This can also be explained by their low scientific literacy level(Dani, 2009).

The study findings reveal the male and female students to have similar social value perceptions. Studies with similar findings can be found upon literature review (Kabadağ and Aladăg, 2010; Özkaynak,1982; Tola, 2003; Kahveci and Demirtaş, 2012). Even though here were no statistically significant variance with respect to gender in this study, the girls were found to have higher mean rank values in values related to honesty and cooperation. The reason for the female students to attribute higher importance than male students to these values may be caused by socially constructed gender roles. Observing the games children play at young ages 
reveals that boys generally play car repair and sports games, whereas girls engage in activities which develop verbal skills such as story listening and play acting with dolls. They regard these dolls as their children and listen to their problems and show empathy and this improves their skills to respect others. (Ruble and Martin, 1998) Furthermore in a study by Dökmen (1999), he points out that the fact that female students are more empathetic, higher inclined to cooperation and more sensitive to humanitarian values may have been shaped by socially constructed gender roles and upbringing differences when instilling these roles.

In this study the social values perceptions do not vary significantly with respect to education level of the mother however vary significantly with respect to education level of the father. It was determined that as the education level of the father gets higher, social values perceptions of the students are more positive. These findings are congruent with findings of studies by Tola (2003) and Durualp and Durualp (2012) Furthermore, Türk and Nalçacı (2011) concluded in their study that there is a positive correlation between the education levels of parents and values learning achievement levels of children. Elevation of the education levels of the parents enables them to transfer their experiences, knowledge and culture to their children which in turn improves the acquisition of the values by children. The main objective of the value selection and the process of transforming values into behavior is to help children when they are choosing their value systems and to guide those children who wish to establish their own moral judgment system (Ruyter, 2002).

The study reveals that the value perceptions vary significantly in favor of students living in the city center. This finding indicates that the place of residence has a significant effect on the ideas on social values of the individual.

Values are closely correlated to the living environment and personal experiences. (Balat and Dağal, 2006) In the study by Furnham (1984) conducted with the objective of comparing three cultures, South Africans were found to place greater emphasis on the values of equality, peace, collaboration, national security and social recognition, where the Europeans favored the values of friendship, mature love, aesthetics, family safety and an exciting life and whereas the Indians adopt a mixture of the values on the previously mentioned two groups on a moderate level. Furnham explains the study results with the historical, cultural, socio-economic structure and requirements of three different cultures. Values influence cognitive processes and personal attitudes and behaviors on one hand and on the other hand interact with and reflect cultural norms of the society. In the study by Hines (2008) the value perceptions adopted by societies were found to diverge from one another. This diversification may be arising from both lifestyles 
and also socio-economic conditions. The individual learns many behaviors unconsciously through the prevailing culture of its society. Therefore the hidden curriculum is emphasized as the strongest tool to be employed in values education. (Wlton and Mallan, 1999)

It is concluded that the fourth grade primary school students are less keen on the values of sensitivity and appreciating beauty, that their social values perceptions do not statistically significantly difference with respect to the education level of the mother and significantly differences with respect to the education level of the father and the place of residence.Parents are keystones of acquiring values process. Therefore trainings on how to instill social values into children may be delivered to the families. Curricula on improving social values perceptions can be developed and experimental studies may be conducted. Furthermore contribution to literature may be accomplished by examining social values perceptions of primary school students in depth by observation and interviews.

\section{References:}

1. Bakaç, E. (2013). Perceptıon scale of social values: Validity and reliability study. Journal of Research in Educationand Teaching. 2(4), 303-309.

2. Balat, G. U. ve Dağal, A. (2006). Okul öncesi dönemde değerler e ğitimi etkinlikleri. Ankara: Kök Yayıncılık.

3. Çubukçu, Z. (2012). İlköğretim öğrencilerinin karakter eğitimi sürecinde örtük programın etkisi. Kuram ve Uygulamada Eğitim Bilimleri Dergisi, 12(2), 1513-1534

4. Dani, D. (2009). Scientific literacy and purposes for teaching science: a case study of Lebanese private school teachers. International Journal of Environmental \& Science Education, 4(3), 288-299.

5. Doğanay, A. (2006). Hayat bilgisi ve sosyal bilgiler öğretimi. C. Öztürk.(Ed.), Ankara: Pegem A Yayınları.

6. Dökmen, Z. Y. (1999). Bem cinsiyet rolü envanteri kadınsılık ve erkeksilik özellikleri Türkçe formunun psikometrik özellikleri. Kriz Dergisi, 7(1), 27-40.

7. Durualp, E. ve Durualp, E. (2012). İlköğretim ikinci kademede öğrenim gören öğrencilerin evrensel değerlere ilişkin tutumların incelenmesi. Kuramsal Ĕgitim Bilim Dergisi, 5(4), 484-499.

8. Furnham, A. (1984).Value systems and anomie in three cultures. International Journal of Psychology, 19, 565-579.

9. Gündüz, M. (2015). Değerler eğitimi. Ankara: Maya Yayıncılık.

10. Hines, A. (2008). Global trends in culture, infrastructure and values. Futurist, 42 (5), 18-23. 
11. Kabadağ, A. ve Aladağ, S. K. (2010). Farklı ilköğretim kurumlarına devam eden öğrencilerin ahlaki gelişimlerinin çeşitli değişkenler açısından incelenmesi. Uluslararası Insan Bilimleri Dergisi, 7(1), 879-898.

12. Kahveci, G. ve Demirtaş, Z. (2012). İlköğretim okulu altıncı, yedinci ve sekizinci sınıf öğrencilerinin temizlik ve hijyen algıları. Pegem Ĕgitim ve Öğretim Dergisi, 2(2),52-61.

13. Norris S. P. ve Phillips, L. M. (2003). How literacy in its fundamental sense is central to scientific literacy. Science Education, 87, 224-240.

14. Öksüz, Y. (2011). 11-12 yaş çocuklarının değerleri kazanım düzeylerinin bazı değişkenler açısından karşılaştırılması: SamsunLancashire Örneği. International Journal of SocialScience, 4(2), 6178.

15. Özensel, E. (2007). Kültürün popülerleşen bir alanı: popüler kültür, kültür sosyolojisi, (Ed. K. Alver ve N. Doğan), Ankara: Hece Yayınları.

16. Özkaynak, B. (1982). Teğmen Kalmaz İlkokulu'na devam eden alttonbir yaş grubu çocukların ahlak yargılarının gelişimi. Yayınlanmamış yüksek lisans tezi, Hacettepe Üniversitesi, Ankara.

17. Ravinger, R. (2006). Value-based education for human development Eritrean perspective. Essays in Education. USA: South Carolina.

18. Ruyter, D. J. (2002). The right to meaningful education: The role of values and beliefs. Journal of Beliefs and Values, 23(1), 33-42.

19. Tola, D. (2003). İlkokul 5.sınıf çocuklarında ahlaki yargı ile anababa tutumları arasındaki ilişkinin incelenmesi. Yayınlanmamış Yüksek lisans tezi, Hacettepe Üniversitesi, Ankara.

20. Tural, S. (1992). Kültürel kimlik üzerine düşünceler. Ankara: Ecdad Yayınevi.

21. Türk, N. ve Nalçacı, A. (2011). İlköğretim beşinci sınıf öğrencilerinin sosyal bilgiler programında verilen değerleri edinme düzeyleri (Erzincan örneği). Erzincan Eğitim Fakültesi Dergisi, 13(2).

22. Welton, D. A. ve Mallan, J. T. (1999). Children and their world. Boston: Houghton Mifflin Company. 